\title{
Analysis of Fraudulent Financial Reporting With the Role of KAP Big Four as a Moderation Variable: Crowe's Fraud's Pentagon Theory
}

\author{
Maylia Pramono Sari ${ }^{1}$, Nindya Pramasheilla ${ }^{1}$, Fachrurrozie $^{1}$, Trisni Suryarini $^{1} \& \operatorname{Imang}$ Dapit Pamungkas ${ }^{2}$ \\ ${ }^{1}$ Faculty of Economics, Universitas Negeri Semarang, Semarang, Indonesia \\ ${ }^{2}$ Faculty of Business and Economics, Universitas Dian Nuswantoro, Semarang, Indonesia \\ Correspondence: Imang Dapit Pamungkas, Faculty of Business and Economics, Universitas Dian Nuswantoro, \\ Semarang, Indonesia. E-mail: imangdapit.pamungkas@dsn.dinus.ac.id
}

Received: June 19, 2020

Accepted: August 17, 2020

Online Published: September 21, 2020

doi:10.5430/ijfr.v11n5p180

URL: https://doi.org/10.5430/ijfr.v11n5p180

\begin{abstract}
The purpose of this study is to provide empirical evidence of pentagon fraud risk factors sush as financial targets, financial stability, number of audit committee members, nature of industry, change in auditors, auditor opinion, change in director, proportion of the independent commissary, frequent number of CEO pictures, and CEO duality on fraudulent financial reporting with KAP big four as a moderating variable. The samples in this study were all state-owned companies listed on the Indonesia Stock Exchange in 2014-2018. The purposive sampling technique was used in sampling so that 55 companies were obtained. This study uses logistic regression analysis techniques with SPSS version 26. The results of the study indicate that financial stability and the auditor's opinion influence the fraudulent financial reporting. However, financial targets, number of audit committee members, nature of industry, change in auditors, change in director, proportion of the independent commissary, frequent number of CEO pictures, and CEO duality not effect on fraudulent financial reporting.
\end{abstract}

Keywords: fraud pentagon, fraudulent financial reporting, kap big four

\section{Introduction}

The performance of a company can be demonstrated by the issuance of financial statements. Financial statements are a financial information and final output of the accounting process in a particular accounting period, its purpose is as a communication tool between financial data or operational activities of a company with various internal and external parties of the company. Every company tries to maintain its existence, so management strives to present financial statements as best as possible. But on the other hand, it triggers management to commit fraud by manipulating financial statements. The practice of fraud has happened both at home and abroad. In Indonesia, one of them is PT. Garuda Indonesia Persero Tbk. the beginning of 2018 recorded a profit of USD 809.85 thousand. This figure jumped sharply compared to 2017 which lost a total of USD 216.58 million. This performance is surprising because in the third quarter of 2018 the company also lost USD 114.08 million. For this violation, OJK dragged KAP Tanubrata Sutanto Fahmi Bambang and Partners as auditors of the company's financial statements. Related to the number of cases of fraud, SAS No. 99 provides guidance for auditors to be more effective in detecting fraudulent financial reporting and assessing various risks that will occur. Cressey, (1953) in the theory of fraud triangle categorizes three factors causing financial statement fraud, namely pressure, opportunity, and rationalization. 2004, meanwhile Wolfe \& Hermanson, (2004) perfecting the theory of fraud triangle by adding one element, namely the capability. Other than that, Crowe's Horwath also involved in the development of fraud theory, namely pentagon fraud in 2011. The research he did added a new element, arrogance.

The gap phenomenon in this study is empirical evidence related to the inconsistency of the results of several previous studies. Research conducted by Tessa \& Harto, (2016); Kurnia \& Anis, (2017) shows that financial target no effect on fraudulent financial reporting. But research Mertha Jaya \& Poerwono, (2019) shows that financial target effect on fraudulent financial reporting. Tessa \& Harto, (2016); Kurnia \& Anis, (2017); Ratnasari \& Solikhah, (2019) shows that financial stability effect on fraudulent financial reporting. Research Zulfa \& Bayagub, (2018); Sasongko \& Wijayantika, (2019) shows that financial stability no effect on fraudulent financial reporting.

Research results from Handoko \& Ramadhani, (2017) which shows that the number of audit committee members no 
effect on fraudulent financial reporting. While research Indriani \& Terzagh, (2017); Marliani, (2019) shows that the number of audit committee member effect on fraudulent financial reporting. Research Sasongko \& Wijayantika, (2019) found that nature of industry no effect on fraudulent financial reporting. While research Kurnia \& Anis, (2017); Indriani \& Terzagh, (2017); Marliani, (2019) shows that nature of industry effect on fraudulent financial reporting. Research conducted Tessa \& Harto, (2016); Kurnia \& Anis, (2017); Lestari \& Henny, (2017) find that result change in auditor no effect on fraudulent financial reporting. While research Putriasih, (2016) show that results change in auditor effect on fraudulent financial reporting. The auditor's opinion has a significant effect on fraudulent financial reporting, Ulfah et al., (2017) but research Aprilia, (2017); Nugraheni \& Triatmoko, (2016) show results auditor's opinion has no influence on fraudulent financial reporting. Tessa \& Harto, (2016); Kurnia \& Anis, (2017) have researched change in director that there is no influence on fraudulent financial reporting. But research Zulfa \& Bayagub, (2018); Sasongko \& Wijayantika, (2019) shows that change in director effect on fraudulent financial reporting. Research Aprilia, (2017); Indriani \& Terzagh, (2017); Kurnia \& Anis, (2017) find that result proportion of the independent commissary no effect on fraudulent financial reporting. While research Putriasih, (2016) show results if proportion of the independent commissary effect on fraudulent financial reporting.

Frequent number of CEO's picture no effect on fraudulent financial reporting this result is a research from Akbar, (2017); Kurnia \& Anis, (2017); Sasongko \& Wijayantika, (2019). However, Tessa \& Harto, (2016); Lestari \& Henny, (2017) show that results Frequent number of CEO's picture effect on fraudulent financial reporting. Research result Akbar, (2017); Sasongko \& Wijayantika, (2019); Ratnasari \& Solikhah, (2019) that CEO duality no effect on fraudulent financial reporting. While, research Yang et al., (2017) that CEO duality effect on fraudulent financial reporting. The novelty is adding several independent variables that are used, among others, the number of audit committee members, nature of the industry, auditor opinion, proportion of the independent committee, frequent number of CEO Picture, and CEO duality.

\section{Literature Review and Hypothesis Development}

\subsection{Agency Theory}

Agency theory was coined by Jensen \& Meckling, (1976) mention there are two parties, namely the principal and agent. The main basis for the emergence of agency theory is because of differences in interests between the two parties (conflict of interest). Principal wants to get a good financial performance in the form of return on investment and expects the agent to be able to realize the interests of the company. While, the agent wants to get a reward from the principal for his performance. Information and extensive knowledge possessed by agents compared to principal lead to assymetric information which will trigger fraud.

\subsection{Pentagon Fraud}

The Crowe's Fraud Pentagon coined by Crowe's (2011). This theory is a renewable theory and the development of the theory of Fraud Triangle and Fraud Diamond proposed by Cressey, (1953) and Wolfe \& Hermanson, (2004). In pentagon fraud theory, Crowe's added one other element of fraud, namely arrogance. Arrogance illustrates the attitude of superiority of a person on the positiowolfen or rights they have, so that they assume that the company's internal control does not apply to him.

\subsection{Financial Targets on Fraudulent Financial Reporting}

Financial target have an agency relationship that will cause a conflict of interest that triggers fraud. According to Skousen et al., (2009) Financial target measurement can use return on assets (ROA) to see how efficient a company's assets are in generating profits. The high value of ROA shows that the company's performance in generating profits is getting better (Lestari \& Henny, 2017; Pamungkas, 2018). Therefore, the higher the value of ROA, the higher the potential for fraudulent financial statements. But on the contrary, if the value of ROA is low, it illustrates the company's financial condition decreases (Chabachib et al., 2019; Irwandi et al., 2019; Pamungkas \& Utomo 2018). This is considered because the auditor's performance is poor and lacks quality. So, the company will choose a qualified auditor so that the company's financial condition improves. Big four KAP is considered to have better quality than non big four KAP. Based on this description, this study proposes the following hypothesis:

H1a: Financial target positive effect on fraudulent financial reporting

H1b: KAP big four weakens the relationship financial target against fraudulent financial reporting

\subsection{Financial Stability on Fraudulent Financial Reporting}

Financial stability related to agency theory. Principal will reward agents for the results of their performance. Therefore the agent will do a variety of ways to display the best performance. SAS No. 99 explains that financial 
stability describe the stability of financial conditions. The company's total assets that decline even negatively cause investors not interested in investing and assume that the company is not able to operate the company's activities and even make a maximum profit. Management will manipulate financial statements to cover the instability of the company's condition (Tessa \& Harto, 2016; Utomo et al., 2019; Wahyudi et al., 2019). The company's total assets are low, so the potential for financial statement fraud is higher. In order to minimize the occurrence of fraudulent financial reporting, the company will use an external auditor as the mediator. Companies will tend to use big four KAPs because they are considered to have better quality than non big four KAPs. Based on this description, this study proposes the following hypothesis:

H2a: Financial stability negative effect on fraudulent financial reporting

$\mathrm{H} 2 \mathrm{~b}$ : KAP big four weakens the relationship financial stability against fraudulent financial reporting

\subsection{The Number of Audit Committee Members on Fraudulent Financial Reporting}

The relationship of the audit committee with agency theory can be seen from its tasks and functions. The audit committee controls management, so that it is not opportunistic. Fraud occurs because internal controls are weak and there is no prevention or prior detection. Audit committees will be ineffective if they are too large or too small (Dalton et al, 1999). Too many audit committee members will result in loss of focus and become less participatory, while an audit committee size that is too small will be less effective because of the lack of skills and knowledge. The size of the audit committee is large, the quality of financial statements is increasingly guaranteed. So, that the number of audit committees can minimize fraud. To support the audit committee's duties so that they can run well and are in line with company demands, the role of external auditors is needed. In addition to assisting the duties of the board of commissioners, the audit committee is also tasked with giving consideration to directors in terms of selecting auditor services. The greater the number of members of the audit committee, the higher the demand for good quality auditors or often called the KAP big four. Based on this description, this study proposes the following hypothesis:

H3a: The number of audit committee member negative effect on fraudulent financial reporting

H3b: KAP big four weakens the relationship of the number of audit committee members against fraudulent financial reporting.

\subsection{Nature of Industry on Fraudulent Financial Reporting}

According to agency theory that the nature of industry arises because of assymetric information. The agent has extensive information and knowledge about the company's condition and future prospects rather than the principal. Nature of industry is calculated using the ratio of changes in receivables (Sihombing \& Rahardjo, 2014). The higher the value of the ratio of changes in the total receivables of a company, the potential for fraudulent financial reporting is also higher. The role of the external auditor is used as a third party in an effort to minimize the occurrence of fraudulent financial reporting (Ghozali et al., 2019; Irwandi et al., 2019; Utomo et al., 2020). High audit quality is indicated by the role of external auditors working in big four KAP companies rather than non big four KAP external auditors. Based on this description, this study proposes the following hypothesis:

H4a: Nature of industry positive effect on fraudulent financial reporting

H4b: KAP big four weakens relations nature of industry against fraudulent financial reporting

\subsection{Change in Auditors on Financial Reporting Fraudulent}

SAS No. 99 explained that the company that changed auditors was indicated to have committed fraud and eliminated fraud trail. Companies that experience financial difficulties in a certain period will lead to bankruptcy. Such conditions will force companies to change auditors. The more often companies make changes in auditors, the higher the fraud that occurs in the company. The purpose of change in auditor in this study, can be in the form of auditor change from KAP big four to KAP non big four, change of auditor KAP non big four to KAP non big four, and KAP big four become KAP non big four. Financial difficulties make companies tend to use auditors with higher quality than before because to gain shareholder trust and reduce risk (Chabachib et al., 2019; Sari et al., 2020). This was done because the big four KAP was considered to be able to produce greater independence, maintained and quality than the non big four KAP. Based on this description, this study proposes the following hypothesis:

H5a: Change in auditor positive effect on fraudulent financial reporting

H5b: KAP big four weakens relations change in auditor against fraudulent financial reporting 


\subsection{Auditor Opinion on Fraudulent Financial Reporting}

The financial statements are presented by management, then the accountants are assessed and their accuracy by the external auditor by issuing an auditor's opinion based on the conditions that occur in the company. In this study, the opinion issued by the auditor in the form of Fair Opinion Without Exception with Explanatory Language. This type of opinion is a form of auditor's tolerance for earnings management practices. Thus, the company obtains an unqualified opinion with an explanatory language, the potential for fraudulent financial reporting in the company is higher. According to Nugraheni \& Triatmoko, (2016), Fair Opinion Without Exception With the Explanatory Language obtained by the company, means that the auditor tolerates earnings management through an explanatory language. So, that the possibility of management will be rational that what it is doing is not wrong. The reputation and big name owned by the auditor is able to provide better quality audit reports including disclosing going concern. Therefore, KAP big four is considered to have better quality than KAP non big four. Based on this description, this study proposes the following hypothesis:

H6a: Auditor's opinion has a positive effect on fraudulent financial reporting

H6b: KAP big four weakens relations auditor's opinion on fraudulent financial reporting

\subsection{Change in Director on Fraudulent Financial Reporting}

Based on agency theory, companies can do change in director to reduce agency conflict between the principal and agent. Agents have a personal interest to obtain their own welfare so it is not in line with the principal's expectations, this is called a conflict of interest. Change in director is a delegation of duties and responsibilities from the old board of directors to the new board of directors with a view to improving the performance of the previous directors by changing the composition of the board of directors and the recruitment of competent directors. Companies make changes to directors, can cause stress periods that will trigger fraud. The more companies do change in director, the higher the potential for report fraud. With the new directors wants to make changes or improvements to accounting, financial, and KAP policies (Pratama \& Ariyanto, 2016). The new directors need better quality auditors who are able to meet the demands of the company. To improve performance, the new directors conducted various methods by selecting big four KAPs that were considered to be of higher quality and capable of detecting fraudulent financial reporting. Based on this description, this study proposes the following hypothesis:

H7a: Change in director positive effect on fraudulent financial reporting

H7b: KAP big four weakens relations change in director against fraudulent financial reporting.

\subsection{Proportion of the Independent Commissioners on Fraudulent Financial Reporting}

The independent board of commissioners is considered to be able to minimize the occurrence of fraud because the independent board of commissioners is a party that has no special relationship with the company. The independent board of commissioners will be responsible for overseeing management's performance. So, that internal supervision becomes better and more effective. The greater the proportion of independent commissioners in a company, the more effective the supervisory function of the company (Carcello et al, (2002); Davidson et.al, (2005); Ganang and Agus, 2017). To realize the important role of the board of commissioners in corporate governance, the independent board of commissioners involves a high quality KAP to assess the quality of information presented by management. The more independent boards of commissioners, the more effective the corporate governance mechanism is expected to be, the selection of qualified auditors will be involved to create reliable information (Hidayah et al., 2020; Utomo et al., 2018). So, that a high quality KAP (KAP big four) can detect fraudulent financial reporting. Based on this description, this study proposes the following hypothesis:

H8a: Proportion of the independent commissary negative effect on fraudulent financial reporting

H8b: KAP big four weakens the relationship of proportion of the independent commissary against fraudulent financial reporting

\subsection{Frequent Number of CEO Pictures on Fraudulent Financial Reporting}

Frequent number of CEO picture is the number of CEO images in the annual report. The number of CEO photos in the company's annual report shows that the CEO wants to be known by the public at large and treat themselves as celebrities (Pamungkas \& Utomo, 2018). The increasing number of CEO photos appearing in the company's annual report, is expected to increase the nature of its arrogance. So, that it is able to commit fraud without fear of internal control. This arrogance character requires the role of an external auditor to minimize fraud, especially in the financial statements. The use of external auditors or big four KAP is more desirable because it can find misstatements compared to companies that use non big four KAP audit services. Based on this description, this study proposes the 
following hypothesis:

H9a: Frequent number of $\mathrm{CEO}$ picture positive effect on fraudulent financial reporting

H9b: KAP big four weakens relations frequent number of CEO picture against fraudulent financial reporting

\subsection{CEO Duality on Fraudulent Financial Reporting}

CEO duality means that the CEO has two positions at once in one company as a board of commissioners. This is considered to cause agency problems with the principal. This condition will have an impact on the low level of corporate supervision function that will be used by several parties to commit fraud (Ratnasari \& Solikhah, 2019). CEO duality signifies poor corporate governance (Yang et al., 2017). The higher the attitude of CEO arrogance with the dual position of CEO Duality, the higher the practice of fraud in the company. According to research Makni et al., (2012) shows that concurrent positions as CEO and board of commissioners have a positive signal to shareholders because their interests will be aligned with the selection of high-quality and well-known auditors. In other words, the combined function of the CEO and the board of commissioners supports the selection of high quality auditors or big four KAPs to detect fraud. Based on this description, this study proposes the following hypothesis:

H10a: Frequent number of CEO picture positive effect on fraudulent financial reporting

H10b: KAP big four weakens relations frequent number of CEO picture against fraudulent financial reporting

Framework for research on the influence of financial targets, financial stability, the number of audit committees, nature of the industry, change in auditor, auditor opinion, change in director, proportion of the independent committee, frequent number of CEO picture, CEO duality on fraudulent financial reporting with KAP big four as a moderating variable can be seen as follows:

\section{Results}

This research is a type of quantitative research using secondary data obtained from annual reports from the company's website or the Indonesia Stock Exchange website. The population in this study are all state-owned companies listed on the Indonesia Stock Exchange in 2014-2018. Purposive sampling is a sample technique used to obtain 55 sample companies with a study period of five years. Following is the selection process based on sample criteria:

Table 1. Sample selection process based on criteria

\begin{tabular}{clcc}
\hline No. & \multicolumn{1}{c}{ Sample Criteria } & $\begin{array}{c}\text { Not } \\
\text { Criteria }\end{array}$ & Amount \\
\hline 1 & BUMN companies go public listed on the IDX during the period 2014 - 2018. & - & 20 \\
\hline 2 & $\begin{array}{l}\text { The company publishes the audited annual report on the company's website or } \\
\text { the IDX website during the period 2014 - 2018. }\end{array}$ & - & 20 \\
\hline 3 & $\begin{array}{l}\text { The company publishes audited annual reports in rupiah currency during the } \\
\text { 2014-2018 period. }\end{array}$ & $(3)$ & 17 \\
\hline 4 & $\begin{array}{l}\text { The company did not present complete data during the period 2014 - 2018 to } \\
\text { calculate the research variables. }\end{array}$ & $(6)$ & 11 \\
\hline & Total companies meet the criteria & - & 11 \\
\hline & Total Samples & \multicolumn{2}{c}{$11 \times 5=55$}
\end{tabular}

Source: Secondary data processed in 2020

\subsection{Operational Research Variables}

The operational definition of variables in this study is divided into three. First the dependent variable is indicated by the fraudulent financial reporting. Both variables are independent by using the indicators contained in Crowe's Fraud Pentagon Theory that is pressure, opportunity, rationalization, competence and arrogance. Third, moderation variables that are proxy with KAP big four. Here are the operational definitions of the research variable: 
Table 2. Operational research variables

\begin{tabular}{|c|c|c|c|}
\hline & Variable & Measurement & Scale \\
\hline X1: & Financial Target & ROA = Earning After Interest Tax/Total Assets & Ratio \\
\hline $\mathrm{X} 2:$ & Financial stability & ACHANGE $=$ Total Asset $(\mathrm{t})-$ Total Asset (t-1)/ Total Assets (t) & Ratio \\
\hline X3: & $\begin{array}{l}\text { The Number of Audit } \\
\text { Committees }\end{array}$ & Total audit committee in the company & Nominal \\
\hline \multirow[t]{3}{*}{ X4: } & \multirow[t]{3}{*}{ Nature of Industry } & RECEIVABLE $=\underline{\text { Recievable }(\mathrm{t})-\text { Recievable }(\mathrm{t}-1)}$ & \multirow[t]{3}{*}{ Ratio } \\
\hline & & Sales (t-1) & \\
\hline & & 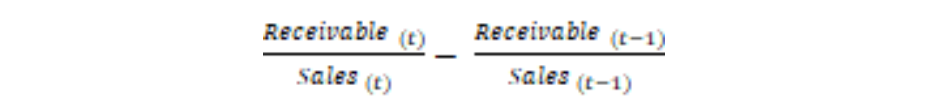 & \\
\hline X5: & Change in Auditor & Dummy variable, changing KAP "1", not changing KAP "0" & Nominal \\
\hline X6: & Auditor's Opinion & $\begin{array}{c}\text { Dummy variable, accepts WTP opinion with explanatory } \\
\text { paragraph "1", does not accept WTP opinion with explanatory } \\
\text { paragraph "0" }\end{array}$ & Nominal \\
\hline X7: & Change in Director & $\begin{array}{l}\text { Dummy variable, Change Directors "1", do not Change Directors } \\
\text { "0" }\end{array}$ & Nominal \\
\hline \multirow[t]{2}{*}{ X8: } & \multirow{2}{*}{$\begin{array}{l}\text { Proportion of The } \\
\text { Dependent Committee }\end{array}$} & IND $=\underline{\text { The Number of Independen Board }}$ & \multirow[t]{2}{*}{ Ratio } \\
\hline & & The Total of Number Commissioners & \\
\hline X9: & $\begin{array}{l}\text { Frequent Number of } \\
\text { CEO picture }\end{array}$ & Total Photos of CEOs in Annual Financial Reports & Nominal \\
\hline X10: & CEO of Duality & $\begin{array}{c}\text { Dummy variable, presence of double position "1", absence of } \\
\text { double position "0" }\end{array}$ & Nominal \\
\hline $\mathrm{Z}:$ & KAP Big Four & $\begin{array}{l}\text { Dummy variable, the company uses Big Four KAP "1", the } \\
\text { company does not use Big Four KAP "0" }\end{array}$ & Nominal \\
\hline Y: & $\begin{array}{l}\text { Fraudulent Financial } \\
\text { Reporting }\end{array}$ & F-Score & Nominal \\
\hline
\end{tabular}

Source: Secondary data processed in 2020

\subsection{Data Analysis Method}

Data analysis method in this research is logistic regression analysis with interaction regression analysis technique. The choice of this analysis method is because the dependent and moderating variables use dummy variables. The use of logistic regression testing ignores the normality test and the classic assumption test on the dependent variable. Analysis tools using SPSS version 26. Testing in this study through several stages, namely descriptive statistical analysis, the overall regression model test, the feasibility test of the regression model, the coefficient of determination test. Here is a model logistic regression equation:

Table 3. Logistic regression equations

\begin{tabular}{lc}
\hline Regression Model & Regression Equation \\
\hline Regression 1 & $\operatorname{Ln} \frac{F}{1-F}=0+1 \mathrm{X} 1+2 \mathrm{X} 2+3 \mathrm{X} 3+4 \mathrm{X} 4+5 \mathrm{X} 5+6 \mathrm{X} 6+7 \mathrm{X} 7+\beta \beta \beta \beta \beta \beta \beta \beta$ \\
$\beta 8 \mathrm{X} 8+9 \mathrm{X}+10 \mathrm{x} 10+\beta \beta \in$ \\
\hline
\end{tabular}


Regression 2

$$
\operatorname{Ln} \frac{F}{1-F}=0+1 \mathrm{X} 1+2 \mathrm{Z}+3 \mathrm{X} 1 \mathrm{Z}+\beta \beta \beta \beta \in
$$

Regression 3

$$
\operatorname{Ln} \frac{F}{1-F}=0+1 \mathrm{X} 2+2 \mathrm{Z}+3 \mathrm{X} 2 \mathrm{Z}+\beta \beta \beta \beta \in
$$

Regression 4

$$
\operatorname{Ln} \frac{F}{1-F}=0+1 \mathrm{X} 3+2 \mathrm{Z}+3 \mathrm{X} 3 \mathrm{Z}+\beta \beta \beta \beta \in
$$

Regression 5

$$
\operatorname{Ln} \frac{F}{1-F}=0+1 \mathrm{X} 4+2 \mathrm{Z}+3 \mathrm{X} 4 \mathrm{Z}+\beta \beta \beta \beta \in
$$

Regression 6

$$
\operatorname{Ln} \frac{F}{1-F}=0+1 \mathrm{X} 5+2 \mathrm{Z}+3 \mathrm{X} 5 \mathrm{Z}+\beta \beta \beta \beta \in
$$

Regression 7

$$
\operatorname{Ln} \frac{F}{1-F}=0+1 \mathrm{X} 6+2 \mathrm{Z}+3 \mathrm{X} 6 \mathrm{Z}+\beta \beta \beta \beta \in
$$

Regression 8

$$
\operatorname{Ln} \frac{F}{1-F}=0+1 \mathrm{X} 7+2 \mathrm{Z}+3 \mathrm{X} 7 \mathrm{Z}+\beta \beta \beta \beta \in
$$

Regression 9

$$
\operatorname{Ln} \frac{F}{1-F}=0+1 \mathrm{X} 8+2 \mathrm{Z}+3 \mathrm{X} 8 \mathrm{Z}+\beta \beta \beta \beta \in
$$

Regression 10

$$
\operatorname{Ln} \frac{F}{1-F}=0+1 X 9+2 Z+3 X 9 Z+\beta \beta \beta \beta \in
$$

Regression 11

$$
\operatorname{Ln} \frac{F}{1-F}=0+1 \mathrm{X} 10+2 \mathrm{Z}+3 \mathrm{X} 10 \mathrm{Z}+\beta \beta \beta \beta \in
$$

Source: Secondary data processed in 2020

\section{Discussion}

\subsection{Hypothesis Test}

The results of testing the hypothesis using logistic regression as follows:

Table 5. Hypothesis test results

\begin{tabular}{cccc}
\hline Variable & p-Value & Sig. & Hypothesis \\
\hline $\mathrm{X} 1 \rightarrow \mathrm{Y}$ & 33,703 & 0.063 & Rejected \\
\hline $\mathrm{X} 2 \rightarrow \mathrm{Y}$ & $-17,703$ & 0.026 & Accepted \\
\hline $\mathrm{X} 3 \rightarrow \mathrm{Y}$ & 1,600 & 0.089 & Rejected \\
\hline $\mathrm{X} 4 \rightarrow \mathrm{Y}$ & $-52,309$ & 0.017 & Rejected \\
\hline $\mathrm{X} 5 \rightarrow \mathrm{Y}$ & $-16,925$ & .999 & Rejected \\
\hline
\end{tabular}




\begin{tabular}{cccc}
\hline $\mathrm{X} 6 \rightarrow \mathrm{Y}$ & 4,375 & 0.048 & Accepted \\
\hline $\mathrm{X} 7 \rightarrow \mathrm{Y}$ & 1,948 & .185 & Rejected \\
\hline $\mathrm{X} 8 \rightarrow \mathrm{Y}$ & 14,269 & .250 & Rejected \\
\hline $\mathrm{X} 9 \rightarrow \mathrm{Y}$ & $-1,156$ & 0.092 & Rejected \\
\hline $\mathrm{X} 10 \rightarrow \mathrm{Y}$ & .257 & 0.895 & Rejected \\
\hline $\mathrm{X} 1 * \mathrm{ZY} \rightarrow \mathrm{Y}$ & 4,310 & .883 & Rejected \\
\hline $\mathrm{X} 2 * \mathrm{ZY} \rightarrow \mathrm{Y}$ & 4,043 & 0.557 & Rejected \\
\hline $\mathrm{X} 3 * \mathrm{ZY} \rightarrow \mathrm{Y}$ & 0.938 & 0.450 & Rejected \\
\hline $\mathrm{X} 4 * \mathrm{ZY} \rightarrow \mathrm{Y}$ & $-13,687$ & .357 & Rejected \\
\hline $\mathrm{X} 5 * \mathrm{ZY} \rightarrow \mathrm{Y}$ & $-1,830$ & 1,000 & Rejected \\
\hline $\mathrm{X} 6 * \mathrm{ZY} \rightarrow \mathrm{Y}$ & $-19,480$ & .999 & Rejected \\
\hline $\mathrm{X} 7 * \mathrm{ZY} \rightarrow \mathrm{Y}$ & 20,551 & .999 & Rejected \\
\hline $\mathrm{X} 8 * \mathrm{ZY} \rightarrow \mathrm{Y}$ & 1,751 & 0.917 & Rejected \\
\hline $\mathrm{X} 9 * \mathrm{ZY} \rightarrow \mathrm{Y}$ & 0.082 & .887 & Rejected \\
\hline $\mathrm{X} 10 * \mathrm{ZY} \rightarrow \mathrm{Y}$ & 17,716 & .999 & Rejected \\
\hline
\end{tabular}

*) Significance level: $0.05(5 \%)$

Source: Secondary data processed in 2020

Table 5 is the result of logistic regression test of parameter estimation and interpretation by looking at the results of SPSS 26 output in the variables in the Equation section. The target financial sig value is 0.063 with a significance level 0.05 . These results indicate that a sig value of $0.063>0.05$. So, testing hypothesis $1 \alpha$ there is no influence between financial targets on fraudulent financial reporting. The value of sig financial stability is 0.026 with a significance level 0.05 . These results indicate that the sig value of $0.026<0.05$. So, testing hypothesis $2 \alpha$ there is no influence between financial stability on fraudulent financial reporting. The sig value of the number of audit committee members is 0.089 with a significance level 0.05 . These results indicate that a sig value of $0.089>0.05$. So, testing hypothesis $3 \alpha$ there is no influence between the number of audit committee members on fraudulent financial reporting. The value of sig nature of industry is 0.017 with a significance level 0.05 . These results indicate that the sig value of $0.017<0.05$. So, testing hypothesis $4 \alpha$ there is no influence of nature of industry on fraudulent financial reporting. The change in auditor sig value is 0.999 with a significance level 0.05 . These results indicate that the sig value of $0.999>0.05$. So, testing hypothesis $5 \alpha$ there is no influence between change in auditor on fraudulent financial reporting. The value of auditor opinion sig is 0.048 with a significance level 0.05 . These results indicate that the sig value of $0.048<0.05$. So, testing hypothesis $6 \alpha$ there is the influence of the auditor's opinion on fraudulent financial reporting. Change in director sig value amounted to 0.185 with a significance level 0.05 . These results indicate that the sig value of $0.185>0.05$. So, testing hypothesis $7 \alpha$ there is no influence between change in director against fraudulent financial reporting. Sig value proportion of the independent commissary amounted to 0.250 with a significance level 0.05 . These results indicate that the value of $\operatorname{sig} \alpha \quad 0.250>0.05$. So, testing hypothesis 8 there is no influence between the proportion of the independent commissary against fraudulent financial reporting. The sig value of the frequent number of CEO pictures of 0.092 with a significant level 0.05 . These results indicate that the value of $\operatorname{sig} \alpha 0.092>0.05$. So, testing hypothesis 9 there is no influence between frequent number of CEO picture against fraudulent financial reporting. CEO duality sig value amount to 0.895 with a significant level 0.05 . These results indicate that the value of $\operatorname{sig} \alpha \quad 0.895>0.05$. So, testing hypothesis 10 there is no influence between CEO duality against fraudulent financial reporting.

The big four KAP sig value moderates the financial target of 0.883 with a significance level 0.05 . These results indicate that the value of $\operatorname{sig} \alpha \quad 0.883>0.05$. So, testing on hypothesis 11 that the role of KAP big four in moderating financial targets has no influence on fraudulent financial reporting. The big four KAP sig value moderates financial stability by 0.557 with a significance level 0.05 . These results indicate that the value of sig $\alpha \quad 0.557>0.05$. So, testing on hypothesis 12 that the role of KAP big four in moderating financial targets has no influence on fraudulent financial reporting. The big four KAP sig value moderates the number of audit committee members by 0.450 with a significance level 0.05 . These results indicate that the value of $\operatorname{sig} \alpha \quad 0.450>0.05$. So, testing on hypothesis 13 that the role of KAP big four in moderating the number of audit committee members has no influence on fraudulent financial reporting. The big four KAP sig value moderates the nature of industry by 0.357 with a significance level 0.05 . These results indicate that the value of $\operatorname{sig} \alpha \quad 0.357>0.05$. So, testing on hypothesis 14 that the role of KAP big four in moderating the nature of industry has no influence on fraudulent financial reporting. Big four KAP big four KAP 
values moderate change in auditor by 1,000 with a significance level 0.05 . These results indicate that the value of $\operatorname{sig} \alpha 1,000>0.05$. So, testing on hypothesis 15 that the role of the big four KAP in moderating change in auditor has no effect on fraudulent financial reporting. The big four KAP big four KAP value moderates the auditor's opinion of 0.999 with a significance level 0.05 . These results indicate that the value of $\operatorname{sig} \alpha \quad 0.999>0.05$. So, testing on hypothesis 16 that the role of KAP big four is in moderating auditor opinion there is no influence on fraudulent financial reporting. The sig value of KAP KAP big four moderates change in director amounted to 0.999 with a significance level 0.05 . These results indicate that the value of $\operatorname{sig} \alpha \quad 0.999>0.05$. So, testing on hypothesis 17 that the role of KAP big four is in moderating change in director there is no influence on fraudulent financial reporting. The big four KAP sig value moderates the proportion of the independent commissary of 0.917 with a significance level 0.05 . These results indicate that the value of $\operatorname{sig} \alpha \quad 0.917>0.05$. So, testing on hypothesis 18 that the role of the big four KAP in moderating the proportion of the independent commissary has no influence on fraudulent financial reporting. The big four KAP sig value moderates the frequent number of CEO pictures of 0.887 with a significance level 0.05 . These results indicate that the value of $\operatorname{sig} \alpha \quad 0.887>0.05$. So, testing on hypothesis 19 that the role of the big four KAP in moderating the frequent number of CEO pictures has no effect on fraudulent financial reporting. The big four KAP sig value moderates CEO duality by 0.887 with a significance level 0.05 . These results indicate that the value of sig $\alpha$ $0.887>0,05$. So, testing on hypothesis 20 that the role of the big four KAP in moderating CEO duality has no effect on fraudulent financial reporting.

\section{Conclusion}

The results of this study is financial target has no effect on fraudulent financial reporting, financial stability has a negative and significant effect on fraudulent financial reporting, the number of audit committee members has no effect on fraudulent financial reporting. But, nature of industry has no effect on fraudulent financial reporting. Change in auditor has no effect on fraudulent financial reporting, however auditor's opinion has a positive effect on fraudulent financial reporting. Change in director has no effect on fraudulent financial reporting. Proportion of the independent commissary has no effect on fraudulent financial reporting, frequent number of CEO picture has no effect on fraudulent financial reporting, CEO duality has no effect on fraudulent financial reporting. Next, Big four KAP cannot weaken the relationship between financial targets and fraudulent financial reporting, The big four KAP was unable to weaken the relationship between financial stability and fraudulent financial reporting and Big four KAP cannot weaken the relationship of the number of audit committee members to fraudulent financial reporting. Big four KAP cannot weaken the nature of industry relationship to fraudulent financial reporting, Big four KAP cannot weaken the relationship between change in auditor and fraudulent financial reporting and Big four KAP cannot weaken the relationship between auditor opinion and fraudulent financial reporting. Big four KAP cannot weaken the relationship between change of directors and fraudulent financial reporting, Big Four KAP cannot weaken the relationship of the proportion of the independent commissary on fraudulent financial reporting and Big four KAP cannot weaken the relationship between the frequent number of CEO picture and fraudulent financial reporting. Big four KAP cannot weaken the relationship between CEO duality and fraudulent financial reporting.

\subsection{Limitations}

The limitation in this research is that it has a relatively small number of samples, the proxy used is still limited, period. Furthermore, the research period is still short, only 5 years. The measurement of the fraudulent financial statement still uses the F-Score. The limitation of this research is that it is hoped that further research will be better. This research is an initial step of research that can open further research. So, that it can further enrich research with this theme.

\subsection{Suggestion}

The following suggestions can be used for future researchers:

1. Future studies are expected to increase the number of samples; other proxies such as institutional ownership, CEO politicians, extending research time; Other measurement models such as Beneish M-Score and Altman Z-Score.

2. For potential investors and investors in investing should pay attention to the information contained in the financial statements, especially on indications of the possibility of fraud.

3. Independent auditors need to maintain their independence in order to maintain relationships with clients and attitudes to make decisions that are not affected by other parties.

4. The public or the public are expected to improve this research so that it becomes reference material for other parties. 


\section{References}

Akbar, T. (2017). The Determination of Fraudulent Financial Reporting Causes By Using Pentagon Theory on Manufacturing Companies in Indonesia. International Journal of Business, Economics and Law, 14(5), $106-113$.

Aprilia, A. (2017). Analisis Pengaruh Fraud Pentagon Terhadap Kecurangan Laporan Keuangan Menggunakan Beneish Model Pada Perusahaan Yang Menerapkan Asean Corporate Governance Scorecard. Jurnal ASET (Akuntansi Riset), 9(1), 101. https://doi.org/10.17509/jaset.v9i1.5259

Chabachib, M., Fitriana, T. U., Hersugondo, H., Pamungkas, I. D., \& Udin, U. (2019). Firm value improvement strategy, corporate social responsibility, and institutional ownership. International Journal of Financial Research, 10(4), 152-163. https://doi.org/10.5430/ijfr.v10n4p152

Chabachib, M., Kusmaningrum, R. H., Hersugondo, H., \& Pamungkas, I. D. (2019). Financial distress prediction in Indonesia. WSEAS Transactions on Business and Economics, 16(2015), 251-260.

Cressey, D. R. (1953). Other people's money; a study of the social psychology of embezzlement.

Ghozali, I., Achmad, T., \& Pamungkas, I. D. (2019). Determinants of fraudulent financial reporting and whistleblowing system: Applying theory of planned behavior. WSEAS Transactions on Business and Economics, $16,393-402$.

Gilang, M. (2017). Pendeteksian Fraudulent Financial Statement Dalam Perspektif Fraud Tiangle.

Handoko, B. L., \& Ramadhani, K. A. (2017). Pengaruh Karakteristik Komite Audit, Keahlian Keuangan Dan Ukuran Perusahaan Terhadap Kemungkinan Kecurangan Laporan Keuangan. DeReMa Jurnal Manajemen, 12(1), 86-113. https://doi.org/10.19166/derema.v12i1.357

Hidayah, R., Indah Fajarini Sri Wahyuningrum, E., \& Nofriyanti, Kiswanto, I. D. P. (2020). Corporate Social Responsibility Disclosure in Indonesia. International Journal of Innovation, Creativity and Change, 11(9), 527-542.

Indriani, P., \& Terzagh, M. T. (2017). Fraund Diamond Dalam Mendeteksi Kecurangan Laporan Keuangan. I-Finance: A Research Journal on Islamic Finance, 3(2), 161-172. https://doi.org/10.19109/ifinance.v3i2.1690

Irwandi, S. A., Ghozali, I., Faisal, \& Pamungkas, I. D. (2019). Detection fraudulent financial statement: Beneish $\mathrm{m}$-score model. WSEAS Transactions on Business and Economics, 16, 271-281.

Jensen, M. C., \& Meckling, W. H. (1976). Theory of the Firm: Managerial Behavior, Agency Costs and Ownership Structure. 2016 Value Summit: The Power of VE.

Kurnia, A. A., \& Anis, I. (2017). Analisis Fraud Pentagon Dalam Mendeteksi Kecurangan Laporan Keuangan dengan Menggunakan Fraud Score Model. Simposium Nasional Akuntansi XX, Jember, 1-30.

Lestari, M. I., \& Henny, D. (2017). Pengaruh Fraud Pentagon Terhadap Fraudulent Financial Statements Pada Perusahaan Perbankan Yang Terdaftar Di Bursa Efek Indonesia Tahun 2015-2017. Jurnal Akuntansi Trisakti, 6(1), 141-156. https://doi.org/10.25105/jat.v6i1.5274

Makni, I., Kolsi, M. C., \& Affes, H. (2012). The impact of corporate governance mechanisms on audit quality of Shari'ah compliant companies. International Journal of Economic Research, 12(5), 2077-2091.

Marliani, N. (2019). Pengaruh Financial Stability, Nature of Industry, Rationalization, dan Change in Director Terhadap Financial Statemen Fraud (Studi Empiris Pada Perusahaan Sub Sektor Logam dan Sejenisnya yang Terdaftar di Bursa Efek Indonesia Periode 2013-2017). Syntax Idea, 1(2), 51-67. https://doi.org/10.1037/0033-2909.I26.1.78

Mertha Jaya, I. M. L., \& Poerwono, A. A. A. (2019). Pengujian Teori Fraud Pentagon Terhadap Kecurangan Laporan Keuangan Pada Perusahaan Pertambangan di Indonesia. Akuntabilitas: Jurnal Ilmu Akuntansi, 12(2), 157-168. https://doi.org/10.15408/akt.v12i2.12587

Nugraheni, N. K., \& Triatmoko, H. (2016). Analisis Faktor-Faktor Yang Mempengaruhi Terjadinya Financial Statement Fraud: Perspektif Diamond Fraud Theory (Studi Pada Perusahaan Perbankan Yang Terdaftar Di Bursa Efek Indonesia Periode 2014-2016). 2002(1), 35-40. https://doi.org/10.1109/ciced.2018.8592188

Pamungkas, I. D., Ghozali, I., Achmad, T., Khaddafi, M., \& Hidayah, R. (2018). Corporate governance mechanisms in preventing accounting fraud: A study of fraud pentagon model. Journal of Applied Economic Sciences, 13(2).

Pamungkas, I. D., \& Utomo, S. D. (2018). Fraudulent financial reporting: An application of fraud pentagon theory to association of southeast Asian nations corporate governance scorecard. Journal of Advanced Research in Law and Economics, 9(5), 1729-1737. https://doi.org/10.14505/jarle.v9.5(35).26 
Pratama, A., \& Ariyanto, D. (2016). Pengaruh Faktor Internal Klien Terhadap Pergantian Kantor Akuntan Publik Upgrade, Downgrade dan Samegrade. E-Jurnal Akuntansi Universitas Udayana, 17(1), 112-140. https://doi.org/10.1017/CBO9781107415324.004

Putriasih, K. (2016). Analisis Fraud Diamond Dalam Mendeteksi Financial Statement Fraud: Studi Empiris Pada Perusahaan Manufaktur Yang Terdaftar Di Bursa Efek Indonesia (Bei) Tahun 2016 - 2018. E-JournalS1 Ak Universitas Pendidikan Ganesha, 6(3). https://doi.org/10.25105/semnas.v0i0.5780

Ratnasari, E., \& Solikhah, B. (2019). Analysis of Fraudulent Financial Statement: The Fraud Pentagon Theory Approach Analisis Kecurangan Laporan Keuangan: Pendekatan Fraud Pentagon Theory. Gorontalo Accounting Journal (GAJ), 2(2), 98-112.

Sari, M. P., Raharja, S., Yulianto, A., Ardiansari, A., Pamungkas, I. D., \& Achmad, T. (2020). Compliance analysis of asia sustainability reporting awards (ASRA) 2018 companies. International Journal of Scientific and Technology Research, 9(3), 3891-3896.

Sasongko, N., \& Wijayantika, S. F. (2019). Faktor Resiko Fraud Terhadap Pelaksanaan Fraudulent Financial Reporting (Berdasarkan Pendekatan Crown'S Fraud Pentagon Theory). Riset Akuntansi Dan Keuangan Indonesia, 4(1), 67-76. https://doi.org/10.23917/reaksi.v4i1.7809

Sihombing, K. S., \& Rahardjo, S. N. (2014). Analisis Fraud Diamond Dalam Mendeteksi Financial Statement Fraud: Studi Empiris Pada Perusahaan Manufaktur yang Terdaftar di Bursa Efek Indonesia (BEI) Tahun 2010 - 2012. Diponegoro Journal of Accounting, 3, 1-12.

Skousen, C. J., Smith, K. R., \& Wright, C. J. (2009). Detecting and predicting financial statement fraud: The effectiveness of the fraud triangle and SAS No. 99. In Corporate governance and firm performance (pp. 53-81). Emerald Group Publishing Limited.

Tessa, C., \& Harto, P. (2016). Fraudulent Financial Reporting: Pengujian Teori Fraud Pentagon Pada Sektor Keuangan Perbankan di Indonesia. Simposium Nasional Akuntansi XIX Lampung, 19, 1-21.

Ulfah, M., Nuraina, E., \& Wijaya, A. L. (2017). Pengaruh Fraud Pentagon dalam Mendeteksi Fraudulent Financial Reporting (Studi Empiris pada Perbankan di Indonesia yang Terdaftar di BEI). Forum Ilmiah Pendidikan Akuntansi, 5(1), 399-417.

Utomo, S. D., Irwandi, S. A., \& Pamungkas, I. D. (2020). Determinants of interpersonal trust in productivity and organisational commitment: Evidence from Indonesia. International Journal of Innovation, Creativity and Change, 11(8), 125-143.

Utomo, S. D., Machmuddah, Z., \& Pamungkas, I. D. (2019). The effect of auditor switching and managerial ownership on fraudulent financial statement. WSEAS Transactions on Business and Economics, 16, 306-315.

Utomo, S. D., Pamungkas, I. D., \& Machmuddah, Z. (2018). The moderating effects of managerial ownership on accounting conservatism and quality of earnings. Academy of Accounting and Financial Studies Journal, 22(6), $1-11$.

Wahyudi, S., Achmad, T., \& Pamungkas, I. D. (2019). Whistleblowing System and Fraud Early Warning System on Village Fund Fraud: The Indonesian Experience. International Journal of Financial Research, 10(6), 211. https://doi.org/10.5430/ijfr.v10n6p211

Wolfe, D. T., \& Hermanson, D. R. (2004). The fraud diamond: Considering the four elements of fraud.

Yang, D., Jiao, H., \& Buckland, R. (2017, (December). The determinants of financial fraud in Chinese firms: Does corporate governance as an institutional innovation matter?. Technological Forecasting and Social Change, 125, 309-320. https://doi.org/10.1016/j.techfore.2017.06.035

Zulfa, K., \& Bayagub, A. (2018). Analisis Elemen-Elemen Fraud Pentagon Sebagai Determinan Fraudulent Financial Reporting. Jurnal Manajemen Dan Akuntansi, 3(2), 950-969. https://doi.org/10.32493/keberlanjutan.v3i2.y2018.p950-969

\section{Copyrights}

Copyright for this article is retained by the author(s), with first publication rights granted to the journal.

This is an open-access article distributed under the terms and conditions of the Creative Commons Attribution license (http://creativecommons.org/licenses/by/4.0/). 